\title{
Sensory Evaluation of Sidestream Odor using Transfer Testing Methodology*
}

\author{
by Lawrence H. Gains and R. S. Marmor
}

Lorillard Research Center, Lorillard, Inc., Greensboro, North Carolina, U.S.A.

\section{SUMMARY}

Cigarettes with closely matched physical characteristics were subjected to static burns inside a modified bell-jar apparatus in order to investigate the effects of variations in cigarette construction and composition on the odor of sidestream smoke. Cambridge filter pads moistened with mineral oil and suspended inside the bell-jars were highly effective transfer materials which captured the sidestream smoke odors. Triangle-test odor evaluations of the exposed Cambridge pads established significant differences at the $95 \%$ confidence level between sidestream odors from cigarettes made with $100 \%$ Burley, flue-cured, or Oriental tabacco. Differences were also found between sidestream odors from tobacco grades within a single tobacco type and between equal blends of two tobacco types. Consistent with studies of sidestream menthol delivery and menthol levels needed to detect a just noticeable difference, no significant sidestream odor differences were found between menthol and non-menthol versions of the same cigarette.

\section{ZUSAMMENFASSUNG}

Zur Untersuchung der Auswirkungen unterschiedlicher Zigarettenkonstruktion und -zusammensetzung auf den Geruch des Nebenstromrauches wurden Zigaretten mit nahezu gleichen physikalischen Merkmalen in einem Glaszylinder mit glockenförmiger Abdeckung (bell-jar)

\footnotetext{
* Presented at the 39th Tobacco Chemists" Research Conference, Montreal, Carsada, 1985.

Received: 11th August 1986 - accepted: 29th April 1987.
}

statischer Verbrennung unterzogen. CambridgefilterScheiben, die mit Mineralöl benetzt und im Innern des Glaszylinders angebracht waren, stellen ein gutes Material zur Absorption und Úbertragung des Nebenstromrauchgeruches dar. Die Untersuchung der Filterscheiben im "Triangel*-Verfahren ergab, daß sich Zigaretten, die jeweils zu 100\% Burley-, Virgin- oder Orienttabak enthielten, im Geruch des Nebenstromrauches bei $95 \%$ iger Vertrauensgrenze signifikant voneinander unterscheiden. Unterschiede im Geruch des Nebenstromrauches zeigten sich auch zwischen verschiedenen Graden innerhalb der einzelnen Tabaktypen und zwischen gleichen Mischungen von zwei Tabaktypen. In Übereinstimmung mit Forschungsarbeiten, in denen der Mentholübergang in den Nebenstromrauch sowie der Schwellenwert untersucht wurde, ab dem Menthol wahrnehmbar ist, ließ sich in den vorliegenden Versuchen kein signifikanter Unterschied im Geruch des Nebenstromrauches bei Zigaretten mit und ohne Menthol feststellen.

\section{RESUME}

Des cigarettes ayant pratiquement les mêmes caractéristiques physiques ont été soumises à une combustion statique dans un cylindre de verre muni d'un couvercle en forme de cloche (bell-jar) dans le but d'étudier les effets qu'ont les variations de construction et de composition des cigarettes sur l'odeur de la fumée secondaire. Les rondelles de filtre Cambridge humectées de pétrole qui avaient été placées à l'intérieur du cylindre constituaient un bon matériau d'absorption et de transmission de l'odeur de la fumée secondaire. Les examens des rondelles de filtre selon le procédé een triangle» ont 
montré qu'il existait des différences significatives (niveau de confiance de $95 \%$ ) entre les odeurs de la fumée secondaire de cigarettes contenant $100 \%$ de tabac Burley, de tabac de Virginie ou de tabac d'Orient. Des différences ont été observées également entre les odeurs de différents grades d'un même type de tabac et entre celles de mélanges identiques de deux types de tabac. En accord avec les études ayant porté sur le passage du menthol dans la fumée secondaire ainsi que sur la valeur limite à partir de laquelle l'odeur de menthol est perceptible, il n'a été constaté aucune différence significative dans l'odeur de la fumée secondaire d'une même cigarette, avec et sans menthol.

\section{INTRODUCTION}

Some sensory aspects of mainstream or sidestream smoke have been reported upon previously by a number of workers including ABDallah (1), ARTHO and Koch (2), Cain (3), Sakuma (4) and Dravnieks (5). Of particular interest to us are the effects of variations in cigarette composition and construction on the odor of sidestream cigarette smoke. The previous attention focused on the distribution of different chemical components between mainstream and sidestream smoke has stimulated a number of workers to develop a wide variety of apparatus which provide for the separate and simultaneous collection of these smoke streams $(6-8)$. The contributions made by various chemical classes to the aroma of cigarette smoke also have been reported by, among others, Rijk and van Battum (9), Philippe (10), Hoffmann and co-workers (11), ConstantinesCU (12), and MoKhNaChev and Kamenshchikova (13). Still others, most notably HoumiNer and co-workers at Philip Morris (14-18) and SPRECKER and co-workers at International Flavors and Fragrances (19-21), have patented materials said to affect sidestream smoke odor. However, the methods used to evaluate these effects are not described in the patents. Previously described methods used for odor evaluation provide for measuring odor thresholds, intensities, profiles, quality, character, or hedonic tone (22). These methods include paper strip blotters, syringe dilution (23), olfactometers of numerous designs (24), odor hoods, odor rooms, sniffing of GC effluent, and a "triangle odor bag" method (25). None of these methods addresses the basic question: can sensory differences be detected among sidestream odors? To investigate this question, a transfer testing method was developed which permits collection and comparison of sidestream odors generated from different cigarettes. Transfer testing methodology has been applied previously to investigations of odor or flavor contamination of food by packaging materials (26). In a typical application, a highly sensitive acceptor material such as butter, chocolate, distilled water, or mineral oil is exposed to a specimen of food packaging material in a closed container. After twelve to twentyfour hours, the transfer materials are smelled or, in some cases, tasted (27). Our method employs Cam- bridge filter pads moistened with mineral oil as transfer materials which are exposed to sidestream smoke by suspending them inside a modified bell-jar apparatus. By using identical chambers, three samples are prepared simultaneously for use in forced-choice triangle difference tests. This paper describes the method in detail and presents the results of odor evaluation experiments by an expert panel.

\section{MATERIALS AND METHODS}

\section{Cigarette Samples}

Sample cigarettes used in the triangle tests were either all machine-made or all handmade. Machine-made test cigarettes used machine-cut tobaccos with a constant width of cut and had uniform circumference and packing density. Handmade test cigarettes ("Supermatic" cigarette machine, The Central Tobacco Manufacturing Company, Ltd.) used hand-cut tobaccos with a constant width of cut, and had uniform circumference and packing density. Test cigarette masses were matched to within ten milligrams. All test cigarettes were conditioned to uniform constant moisture content by storage in a chamber maintained at $60 \% \pm 1 \%$ relative humidity and $23.9^{\circ} \mathrm{C} \pm 0.3^{\circ} \mathrm{C}$. Conditioned cigarettes were sealed in plastic bags immediately after removal from the conditioning chamber and were used within two hours. Whenever possible, both air dilution and pressure drop were matched for a group of test cigarettes. When both the pressure drop and the air dilution could not be matched simultaneously for a group of test cigarettes, the air dilution was matched to within a maximum air dilution difference of three percent. Table 1 summarizes the physical characteristics of the test cigarettes used for triangle comparisons. Since the cigarettes had uniform circumference, packing density, mass, and moisture content, equal masses of tobacco could be burned by consuming a standard length of the cigarettes. Cigarettes used for comparison were ignited by burning a $12 \mathrm{~mm}$ length under suction. Static burns consumed an additional $30 \mathrm{~mm}$ or $40 \mathrm{~mm}$ on $85 \mathrm{~mm}$ or $100 \mathrm{~mm}$ filter cigarettes respectively.

Table 1.

Test cigarette physical parameters.

\begin{tabular}{c|c|c}
\cline { 2 - 3 } & $\begin{array}{c}\text { Circum- } \\
\text { ference } \\
(\mathrm{mm})\end{array}$ & $\begin{array}{c}\text { Total cigarette } \\
\text { mass } \\
(\mathrm{g})\end{array}$ \\
\hline $\begin{array}{c}\text { machine-made } \\
85 \mathrm{~mm}\end{array}$ & $24.92 \pm 0.18 \mathrm{~mm}$ & $0.93 \pm 0.01 \mathrm{~g}$ \\
$100 \mathrm{~mm}$ & $24.85 \pm 0.11 \mathrm{~mm}$ & $1.05 \pm 0.01 \mathrm{~g}$ \\
handmade & $25.04 \pm 0.09 \mathrm{~mm}^{*}$ & $0.96 \pm 0.01 \mathrm{~g}$ \\
$85 \mathrm{~mm}$ & $24.95 \pm 0.08 \mathrm{~mm}^{*}$ & $1.10 \pm 0.01 \mathrm{~g}$ \\
\hline $100 \mathrm{~mm}$ &
\end{tabular}

* Machine-made cigarettes were emptied of tobacco and the emptied tubes were reused for repacking the handmade cigarettes. 


\section{Tobaccos}

The Burley tobacco used was a blend of stalk positions from Tennessee and Kentucky. The flue-cured tobacco consisted of a blend of stalk positions from various belts. The Oriental tobacco used represented a blend of various grades from various producing areas. Cigarettes prepared for comparison of grades within a tobacco type were made with either $100 \%$ Burley cutters or $100 \%$ leaf Burley.

\section{Transfer Testing Apparatus}

Figure 1 shows the glass bell-jar apparatus used by us. It is similar to an apparatus described by JoHNson and co-workers (28). However, the present work did not require provisions for generating or collecting mainstream smoke. The bell-jar dimensions are approximately $13 \mathrm{~cm} \times 20 \mathrm{~cm}$ with a volume of about $2.6 \mathrm{li}-$ ters. The transfer materials are prepared by applying odorless U.S.P. grade mineral oil $(0.5 \mathrm{ml})$ to the coarse side of standard $45 \mathrm{~mm}$ diameter Cambridge filter pads which have been conditioned at $60 \%$ relative humidity and $23.9^{\circ} \mathrm{C}$. Slots, offset from center in the bell-jar tops, provide for introduction and removal of the Cambridge filters. The pads are threaded onto glass skewers as shown in Figure 2. A standard laboratory jack and supports are used to position the pads to an identical depth in each of the bell-jars. Test cigarettes are ignited under suction and then placed on ashtrays under each bell-jar for a static burn. By positioning the pads to the top rear of the bell-jar center and the cigarettes under bottom front of the bell-jar center, the rising smoke column is subject to convection current mixing before impinging on the pads (Figure 3 ). The pads are oriented uniformly such that the coarse side faces
Figure 1.

Glass bell-jar apparatus.

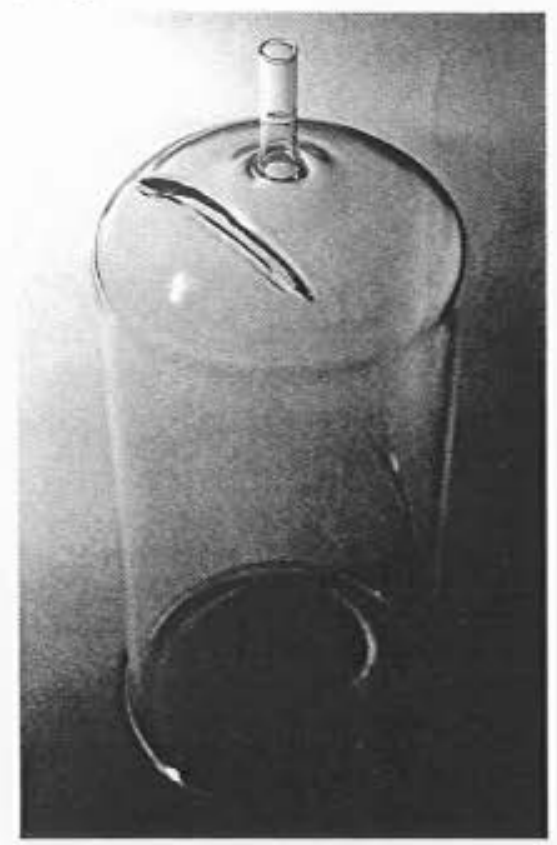

the interior of the bell-jar. After exposure, the odorimpregnated materials are immediately sealed in odorfree plastic bags until sensory analysis is performed. The test cigarettes, bell-jars, and plastic bags are coded with corresponding random three-digit numbers. Sensory evaluations are performed by an expert panel of between five and twelve members containing both smokers and non-smokers. The number of correct selections out of the total number of judgements is compared to a table giving the number of correct identifications required for significance at various levels in a triangle test (26).

Figure 2. Threading of Cambridge filters onto glass skewers.

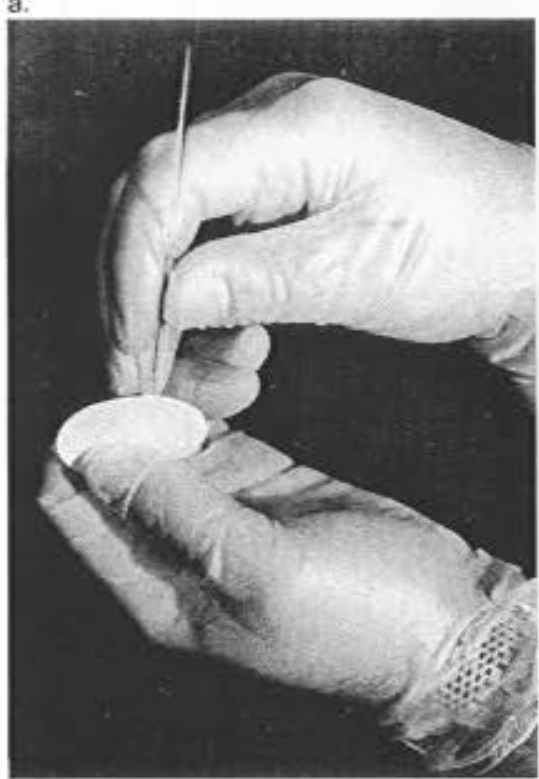

b.

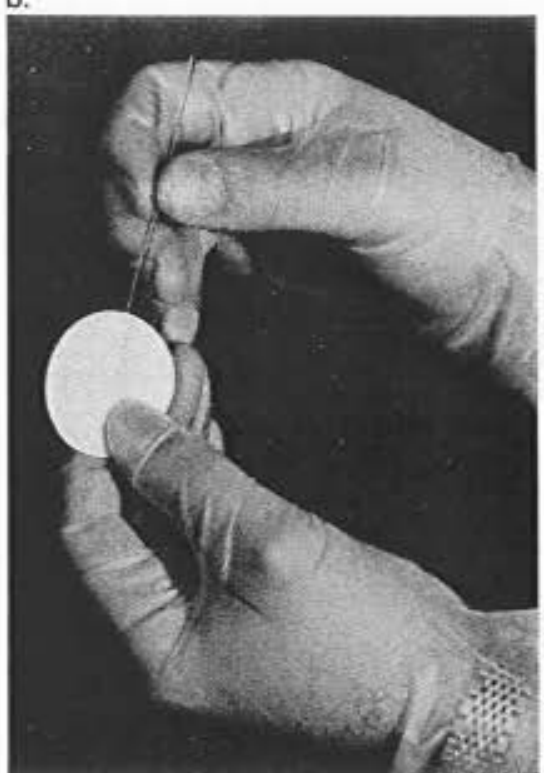

c.

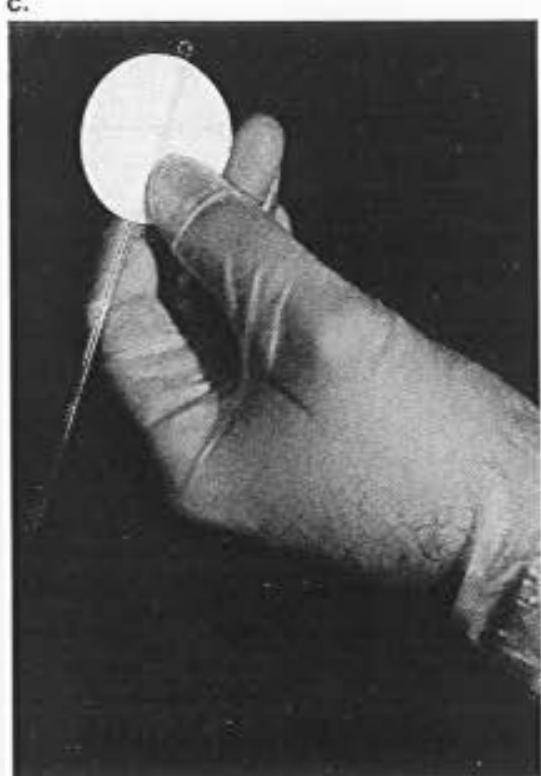


Figure 3. Positioning of transfer materials and cigarettes.

a.

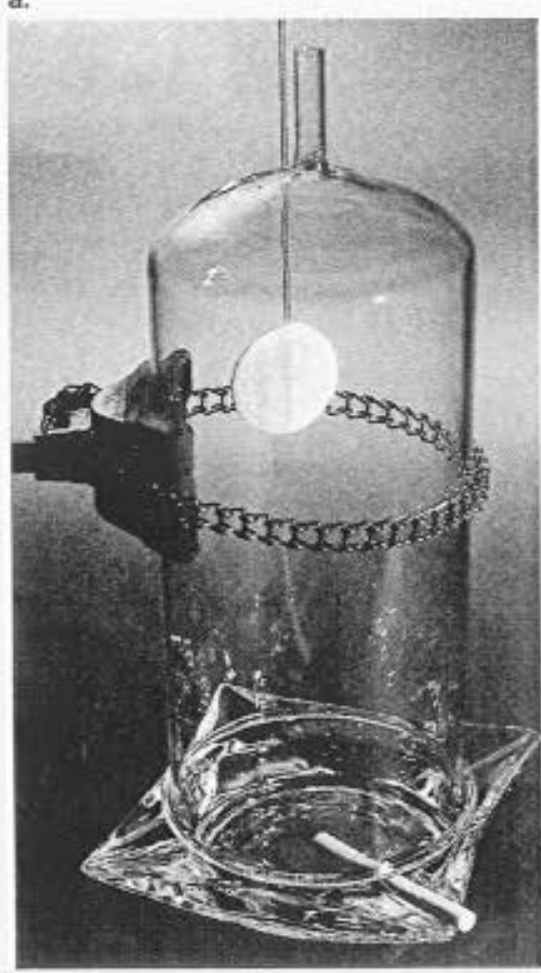

b.

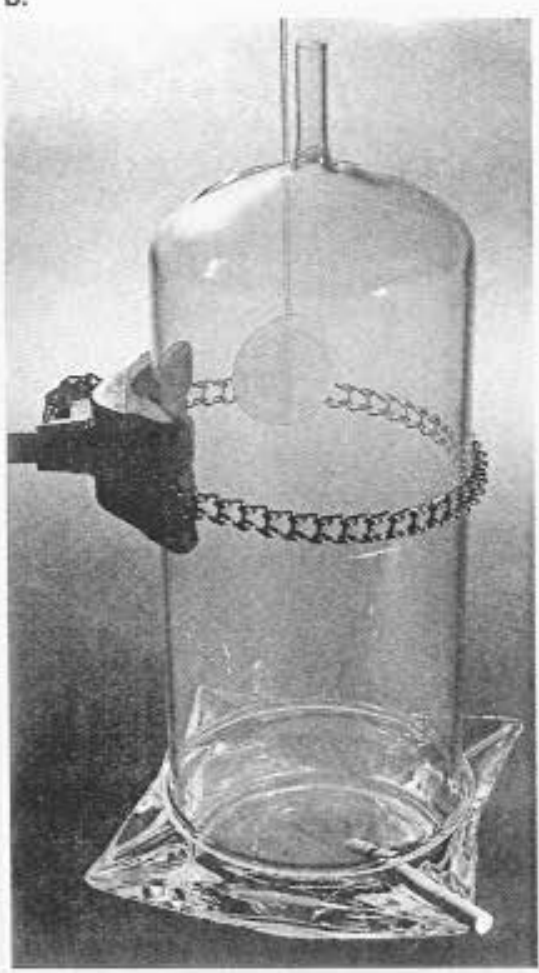

Table 2.

Triangle-test results.

\begin{tabular}{|c|c|c|c|c|c|c|c|}
\hline $\begin{array}{l}\text { Tobacco content } \\
\text { of two out of three } \\
\text { cigarettes }\end{array}$ & $\begin{array}{l}100 \% \\
\text { Burley }\end{array}$ & $\begin{array}{c}100 \% \\
\text { Oriental }\end{array}$ & $\begin{array}{c}100 \% \\
\text { flue-cured }\end{array}$ & $\begin{array}{c}\text { Flue-cured } \\
\text { + Burley } \\
(1: 1)\end{array}$ & $\begin{array}{l}\text { Flue-cured } \\
+ \text { Oriental } \\
(1: 1)\end{array}$ & $\begin{array}{c}\text { Burley + } \\
\text { Oriental } \\
(1: 1)\end{array}$ & $\begin{array}{c}\text { Oriental + } \\
\text { Burley + } \\
\text { flue-cured } \\
(1: 1: 1)\end{array}$ \\
\hline $100 \%$ Burley & no & yes & yes & yes & yes & yes & no \\
\hline $100 \%$ Oriental & yes & no & yes & yes & yes & yes & no \\
\hline $100 \%$ flue-cured & yes & yes & no & yes & yes & yes & no \\
\hline Flue-cured + Burley $(1: 1)$ & yes & yes & yes & no & yes & yes & no \\
\hline Flue-cured + Oriental (1:1) & yes & yes & yes & yes & no & yes & no \\
\hline Burley + Oriental (1:1) & yes & yes & yes & yes & yes & no & no \\
\hline Oriental + Burley + flue-cured $(1: 1: 1)$ & no & no & no & no & no & no & no \\
\hline
\end{tabular}

"NO" indicates no significant difference established.

"res" indicates a statistically significant difference found at the $95 \%$ confidence level or better-

Results of "blank" or "control" triangles, using all three cigarettes of the same composition, appear on the diagonal. 


\section{RESULTS}

Using this methodology, we found statistically significant differences between sidestream odors from cigarettes made with different tobacco samples as summarized in Table 2. Test cigarettes made with $100 \%$ Burley, flue-cured, or Oriental tobacco were all reproducibly different with respect to sidestream odors as established by forced-choice triangle tests. In each case, the number of correct selections corresponded to at least the $95 \%$ confidence level and, in many cases, to the $99 \%$ confidence level.

Replicate experiments in which the odd sample was varied with respect to tobacco type and to the specific test chamber occupied confirmed the results in every combination. Reevaluation of a given set of pads yielded reproducible differences up to sixty-five hours after the set of pads had been exposed to sidestream odor. Sidestream odors from cigarettes made with blends consisting of equal parts of two tobacco types were different from each other and from sidestream odors from the cigarettes made with just a single type of tobacco. No differences were found in sidestream odors from cigarettes prepared by blending equal parts of all three tobacco types when they were compared to sidestream odors from the other cigarettes mentioned above. A difference was established between sidestream odors from cigarettes made with Burley cutters compared to cigarettes made with leaf Burley.

Numerous "blank" or "control" triangles were performed using all three cigarettes made with identical tobacco types, grades, or blends. No significant differences were found in any of these trials. No differences were established by comparisons among different commercial brands except when constructions were radically different. Neither were differences found when comparing sidestream odors from menthol and nonmenthol versions of the same cigarette.

\section{DISCUSSION}

PERFETTI and co-workers have recently reported on the level of menthol in mainstream smoke needed to detect a just noticeable difference (29). Newell (30) and JENkINS (31) have previously quantitated menthol distribution between mainstream and sidestream smoke. Consideration of both sets of data shows sidestream menthol delivery is about the same as that amount required to just detect a difference in mainstream cooling. Hence, even if $100 \%$ of sidestream menthol is captured by the Cambridge pads in our experiments, the fact that we did not find a difference in sidestream odors between menthol and non-menthol cigarettes is consistent with PeRfetTr's results.

Cotton balls or swatches of different cloth material together with odor-neutral water as a fixative material were found to give less consistent results than the combination of Cambridge filter pads with mineral oil. Sidestream smoke has a complex composition including particulate matter plus liquids and gases of varying polarity and volatility. Moreover, while some compounds responsible for odors are well known and can be chemically determined, the large number of odorous compounds and their unknown interactions require sensory evaluation of a representative sample of the odorous mixture (32). Cambridge pads which have been conditioned at $60 \%$ relative humidity and $23.9^{\circ} \mathrm{C}$ and then treated with mineral oil were anticipated to capture such a representative sample. Unconditioned pads were found to give less consistent results. Both dry cotton balls and dry Cambridge pads were inferior odor traps compared to these materials moistened with either odor-neutral water or mineral oil as fixatives. The precise depth of the pads within the bell-jars can be varied without adversely affecting the results. However, it is important that the pads not be positioned directly above the burning cones of the cigarettes (see Figure 3).

Comments by the expert panel members provided guidance in establishing the optimum fixative quantity. Some amounts of fixative yielded high odor levels which resulted in adaptation effects among some panel members. Conversely, low fixative levels sometimes were satisfactory for some panelists but yielded undetectably low odor levels for others among the panelists. Consistent results among all the panelists were obtained when 0.5 milliliter of mineral oil fixative was used.

SPEARs (33) and others $(34,35)$ have commented on the effects of manufacturing variables on cigarette smoke composition. Aust and co-workers have pointed out the importance of comparing treatment effect magnitudes with magnitudes of batch-to-batch variation when doing sensory evaluation of heterogeneous product types such as cigarettes (36). For consistent results in our experiments, it was necessary to use cigarettes with very closely matched physical characteristics including circumference, mass, air dilution, and moisture content. Moisture content clearly will influence smoke chemistry and thus sidestream odor. If one assumes production of odor components to be proportional to mass of tobacco burned, then it should be more important that equal masses of tobacco be burned than that test cigarettes be burned for equal time intervals when comparing sidestream odors. The effect of cigarette circumference on formation rates of smoke components has been documented (37). Others have reported that the chemical content of smoke streams varies with air dilution but not with pressure drop (38). Nevertheless, it is unexpected that air dilution rather than pressure drop was found to be more important to odor differences generated during static burns. Perhaps odor differences are created during the lighting under suction of cigarettes with different air dilutions, and these differences then confound the odor characteristics generated during the static burn phase.

Transfer testing methodology provides for the side-byside comparison of sidestream odors. However, valid results require careful preparation of the sample cigarettes. It is difficult to match the physical characteris- 
tics of the test cigarettes, even if machine-made cigarettes are employed. Important but slight differences in sidestream odors may escape detection by transfer testing methodology.

\section{REFERENCES}

1. Abdallah, F.: Can tobacco quality be measured?; Lockwood Publishing Company, Inc., New York, N.Y., 1970.

2. Artho, A., and R. Koch: Characterization of the offactory properties of cigarette smoke components; Ann. Tab. (Section 1) 11 (1973) 37-43.

3. Cain, W. S.: Sensory attributes of cigarette smoking; in Banbury Report 3: A safe cigarette?, edited by Gio B. Gori and Fred G. Bock, Cold Spring Harbor Laboratory, Cold Spring Harbor, New York, 1980, pp. 239-249.

4. Sakuma, H., M. Kusama, S. Munakata and S. Sugawara: Irritation and paper-burning aroma of cigarette smoke derived from celluluse; Jpn. Monop. Corp. Cent. Res. Inst. Sci. Pap. 122 (1980) 21-31.

5. Dravnieks, A., A. O'Donnell and H. G. Reilich: Determination of odor components in tobacco smoke - Design of mixture to simulate odor; ashrae Trans. Vol. 81, Part 2, 1975, 200-212.

6. Neurath, G., and H. Ehmke: Apparatur zur Untersuchung des Nebenstromrauches; Beitr: Tabakforsch. 2 (1964) 117-121.

7. Klus, $H$., and $H$. Kuhn: Verteilung verschiedener Tabakrauchbestandteile auf Haupt- und Nebenstromrauch (Eine Übersicht); Beitr. 'Tabakforsch. Int. 11 (1982) 229-265.

8. Griffith, R. B.: A simple machine for smoke analytical studies and total particulate matter collection for biological studies; Toxicology 33 (1984) 33-41.

9. Rijk, M. A. H., and D. van Battum: Eine schnelle Bestimmungsmethode für Benz-(a)-pyren in Raucharomen; Dtsch. Lebensm. Rundsch. 69 (1973) 75-78.

10. Philippe, R. J.: Dimethyl sulfide in cigarette smoke - On the origin of the sulfur compounds of cigarette smoke and on their possible contribution to its overall flavor and aroma; Beitr. Tabakforsch. 3 (1966) 577--582.

11. Patrianakos, C., and D. Hoffmann: Chemical studies on tobacco smoke, LXIV. On the analysis of aromatic amines in cigarette smoke; J. Anal. Toxicol. 3 (1979) 150-154.

12. Constantinescu, $T$.: Influence of beta-pyridine alkaloids from tobacco on taste and aroma of cigarette smoke; Lucr.' Cercet. Inst. Cercet. Proiect. Aliment. 10 (1972) 257-268.

13. Mokhnachev, I. G., and S. Kamenshchikova: Carbonyl compounds in tobacco smoke and their effect on the aroma; Sb. Nauchno-Issled. Rab. Vses. Nauchno-Issled. Inst. Tab. Makhorki 155, 1970, $48-52$.
14. Houminer, Y., and H. J. Grubbs: U.S. Patent No. 4,312,368, assigned to Philip Morris, Inc., 1982.

15. Grubbs, H. J., and Y. Houminer: U.S. Patent No. 4,473,085, assigned to Philip Morris, Inc., 1984.

16. Houminer, Y., and E. B. Sanders: U.S. Patent No. 4,259,969, assigned to Philip Morris, Inc., 1981.

17. Houminer, Y., and K. F. Podraza: U.S. Patent No. 4,509,537, assigned to Philip Morris, Inc., 1985.

18. Podraza, K. F.: U.S. Patent No. 4,578,486, assigned to Philip Morris, Inc., 1986.

19. Hall, J. B., M. A. Sprecker, F. L. Schmitt and M. H. Vock: U.S. Patent No. 4,081,479, assigned to International Flavors \& Fragrances, Inc., 1978.

20. Hall, J. B., F. L. Schmitt, E. J. Shuster, M. A. Sprecker and J. F. Vinals: U.S. Patent No. $4,115,431$, assigned to International Flavors \& Fragrances, Inc., 1978.

21. Kiwala, J., B. D. Mookherjee, F. L. Schmitt, M. A. Sprecker, R. W. Trenkle, J. F. Vinals and M. H. Vock: U.S. Patent No. 4,281,177, assigned to International Flavors \& Fragrances, Inc., 1981.

22. Dravnieks, A., T. Masurat and R. A. Lamm: Hedonics of odors and odor descriptors; J. Air Pollut. Control Assoc. 34 (1984) 752-755.

23. American Society for Testing and Materials (ASTM): Measurement of odor in atmospheres (dilution method), D 1391-78, 1978.

24. Dravnieks, A., W. H. Prokop and W. R. Boehme: Measurement of ambient odors using dynamic forced-choice triangle olfactometer; J. Air Pollut. Control Assoc. 28 (1978) 1124-1130.

25. Matsuo, T., K. Doi and K. Amano: The measurement of odor concentration of cigarette smoke by the triangle odor bag method; Jpn. Monop. Corp. Cent. Res. Inst. Sci. Pap. 125 (1983) 33-39.

26. American Society for Testing and Materials (ASTM): Manual on sensory testing methods, Special Technical Publication No. 434, 1968.

27. Sjostrom, L、 B., and F. Sullivan: Testing for odor and taste transfer properties of polymers; in Testing of polymers, Vol. 1, edited by J. Schmitz, Wiley Interscience, New York, N.Y., 1965, pp. 367-376.

28. Johnson, W. R., R. W. Hale, J. W. Nedlock, H. J. Grubbs and D. H. Powell: The distribution of products between mainstream and sidestream smoke; Tob. Sci. 17 (1973) 141-144.

29. Perfetti, T. A., and H. H. Gordin: Just noticeable difference studies of mentholated cigarette products; Tob. Sci. 29 (1985) 57-66.

30. Newell, M. P., P. H. Latimer and L. R. Haefele: The fate of menthol in cigarette smoke; 22nd 'Tobacco Chemists' Research Conference, Richmond, Virginia, 1968.

31. Jenkins, R. W., Jr., R. H. Newman and M. K. Chavis: Cigarette smoke formation studies, II. Smoke distribution and mainstream pyrolytic composition of added ${ }^{14} \mathrm{C}$-menthol (U); Beitr. Tabakforsch. 5 (1970) 299-301.

32. Seigel, J. L., and J. P. McRae: Practical ideas in flavor taste testing; Proc. Am. Soc. Brew. Chem. 32 (1974) 60-64. 
33. Spears, A. W.: Effect of manufacturing variables on cigarette smoke composition; presented at the corESTA Symposium held in Montreux, Switzerland, in 1974, CORESTA Information Bulletin 1974, Special Issue, pp. 65-78.

34. Arany-Fuzessery, K., I. Hamza-Nagy and I. NagyBuday: The effect of physical characteristics of cigarettes on their burning properties and on the major components of the mainstream smoke; Acta Aliment. Acad. Sci. Hung. 11 (1982) 143-155.

35. Yamazaki, M., and S. Saito: Effect of physical properties of cigarettes on the content of carbonyl compounds in the mainstream smoke, 2. Effect of moisture content of tobacco shreds and cigarette circumference; Jpn. Monop. Corp. Cent. Res. Inst. Sci. Pap. 120 (1978) 15-21.

36. Aust, L. B., M. C. Gacula, S. A. Beard and R. W. Washam: Degree of difference test method in sensory evaluation of heterogeneous product types; J. Food Sci. 50 (1985) 511-513.

37. Yamamoto, T., Y. Suga, C. Tokura, T. Toda and T. Okada: Effect of cigarette circumference on formation rates of various components in mainstream smoke; Beitr. Tabakforsch. Int. 13 (1985) 81-87.
38. Grabuloski, T. K., and C. K. Peruseska: Influence of physical properties of cigarettes on the chemical composition of tobacco smoke; Tutun 25 (1975) $439-450$.

\section{Acknowledgements}

We wish to thank Mr. Dave Smart and Mrs. Rebecca Wright for important contributions to this work and extend special thanks to all members of our Expert Panel.

Autbors'address:

Lorillard Research Center,

P. O. Box 21688,

420 English Street,

Greensboro, N.C., 27420-1688, U.S.A. 